IBAD Sosyal Bilimler Dergisi

IBAD Journal of Social Sciences

dergipark.org.tr/ibad

IBAD, 2022; (12): 17-32

DOI: $10.21733 /$ ibad.943336

Özgün Araştırma / Original Article

\title{
Zengin Okul Çevresi, Büyük Öz Kaynak: Okul Aile Birliği Gelirlerinin Okul Çevresinin Sosyoekonomik Düzeyine Göre İncelenmesi
}

Great Equity in Rich School Environment: An Analysis of the Income of the Parent-teacher Association According to the Socioeconomic Level of the School Environment

\author{
Metin Özkan ${ }^{1^{*}}$ \\ Neytullah Karakurt ${ }^{2}$ \\ İlyas Yaşar ${ }^{3}$ \\ * Sorumlu yazar \\ Corresponding author \\ ${ }^{1}$ Doç. Dr., Gaziantep Üniversitesi, Türkiye \\ Assoc. Prof. Dr., Gaziantep University, Turkey \\ ozkan.metin@gmail.com)
}

ORCID ID https://orcid.org/0000-0002-4891-9409

${ }^{2}$ Doktora Öğrencisi, Gaziantep Üniversitesi, Türkiye

PhD. Student, Gaziantep University, Turkey

neytullahkarakurt@gmail.com

ORCID ID https://orcid.org/0000-0001-8798-3350

${ }^{3}$ Doktora Öğrencisi, Gaziantep Üniversitesi, Türkiye

PhD. Student, Gaziantep University, Turkey

ilyasyasar2010@hotmail.com

ORCID ID https://orcid.org/0000-0001-5628-8582

Makale geliş tarihi / First received : 26.05.2021

Bilgilendirme / Acknowledgement:

Yazar(lar) aşağıdaki billgilendirmeleri yapmaktadır(lar):

1- Araştırmacılar tez yazım sürecinde ve tezin makaleye dönüştürülme sürecinde ortak bir çalışma yürütmüştür. Makale katkı oranıc eşittir ancak makalenin dergiye sunumu, takip edilmesi ve sonlandırılması sürecini birinci yazar yapmiştır.

2- Makalenin yazarları arasında çıkar çatışması bulunmamaktadır.

3-Araştırma Gaziantep Üniversitesi Sosyal ve Beşeri Bilimler Etik Kurulu Komisyonu tarafından çalışmanın amacı, yöntemi, veri kaynakları ve veri toplama araçları açısından değerlendirilmiş olup, Komisyonun 01.06.2021 tarih ve 08 nolu toplantısında alınan 17 nolu kararıyla etik açıdan uygun olduğuna karar verilmiştir.

4- Bu makalede araştırma ve yayın etiğine uyulmuştur.

This article was checked by iThenticate. Similarity Index 13\%

Atıf bilgisi / Citation: Özkan, M., Karakurt, N. \& Yaşar, İ. (2022). Zengin okul çevresi, büyük öz kaynak: Okul aile birliği gelirlerinin okul çevresinin sosyoekonomik düzeyine göre incelenmesi. IBAD Sosyal Bilimler Dergisi, (12), 17-32. 
ÖZ

Devlet okulları büyük oranda kamusal kaynaklarla finanse edilmekle birlikte okul aile birliği gelirleriyle öz gelir yaratma ihtiyacı duymaktadırlar. Öz gelirler okulların özellikle cari harcamalarının karşılanmasında önemli bir yer tutabilmektedir. Ancak okulların öz gelirlerinin okul bölgesinin sosyoekonomik düzeyine göre farklılaşması eğitimde sosyal adaletsizliğe kaynaklık edebilir. Bu araştırmanın amacı okul aile birliği gelirlerinin okulun hizmet alanı sınıflandırmasına göre farklılık gösterip göstermediğinin belirlenmesidir. Araştırmada büyükşehir kapsamındaki merkez iki ilçenin ilk, orta ve liselerinin tamamının okul aile birliği gelirleri ile hizmet alanı sinıflandırması veri kaynağ olarak kullanılmıştır. Hizmet alanı bölgesine göre zorunlu hizmet bölgesi kapsamındaki okullarla, diğer okullar arasındaki öğrenci başına okul aile birliği gelirleri karşılaştırılmıştır. İlk ve orta okul düzeyinde her iki ilçede de zorunlu hizmet bölgesi aleyhine öğrenci başı okul aile birliği gelirlerinin anlamlı bir şekilde farklılaştığı görülmüştür. Lise düzeyinde ise ilçenin birinde fark anlamlı bulunmazken, diğerinde yine zorunlu hizmet bölgesi aleyhine fark bulunmuştur.

\section{Anahtar kelimeler}

Okul Aile Birliği, Okul Finansmanı, Öz Kaynak, Okul Çevresi, Sosyoekonomik Düzey

\section{ABSTRACT}

Although public schools are largely financed by public funds, they need to generate self-income with the incomes of the parent-teacher association. Equity capital can play an important role in meeting the current expenditures of schools. However, the differentiation of self-income of schools according to the socio-economic level of the school district may be a source of social injustice in education. The purpose of this research is to determine whether the parentteacher association incomes differ according to the service area classification of the school. In the study, incomes of parent-teacher association and service area classification of all primary, secondary and high schools of two central districts within the scope of metropolitan cities were taken. The income per student of the parent-teacher association between the schools in the compulsory service area and the other schools was compared according to the service area. It has been observed that in both districts at the primary and secondary school level, the parent-teacher association income per student differed significantly against the compulsory service area. At the high school level, there was no significant difference in one of the districts, while the difference was found against the compulsory service region in the other.

\section{Keywords}

Parent-teacher Associations, Finance of School, Equity, School Environment, Socioeconomic level 


\section{GİRIŞ}

Eğitim, devletler tarafından önemli miktarda kaynak ayrılan toplumsal bir alt sistemdir. Devletlerin eğitime yatırım yapması ve eğitimin finansmanını güçlendirmeye çalışmasının nedeni eğitimden bireysel ve toplumsal anlamda elde edilen yararların olduğu söylenebilir. Bireylerin eğitim hakkını da düşünerek devletler, eğitimi geçmişten bugüne artan bir önem ve bütçeyle sürdürmüşlerdir. Eğitim bireysel haklar arasında sayılarak fırsat ve imkân eşitliğinin güçlü bir aracı olarak değerlendirilmektedir. Eğitim, toplumları geliştirip dönüştürebilecek dışsallıklara sahiptir. Eğitime yapılan yatırım, kalkınma sürecinin kilit unsuru olarak görülmektedir (Psacharopoulos ve Woodhall, 1993). Eğitim, çoğu toplumda insan sermayesine yapılan yatırımın en büyük bileşenini temsil eder. Cinsiyetler arasında eğitimin etkileri düşünüldüğünde kadınların okullaşma sürelerinin erkeklere göre daha büyük sosyal getirilere sahip olduğu görülmektedir (Schultz, 2002). Görüldüğü gibi eğitim hem ekonomik kalkınmada rol oynamakta hem de toplumda kadınlar açısından dezavantajlı durumların oluşmasını engellemektedir. Eğitimli nüfusun artmasıyla doğumda yaşanan ölü bebek ve bebek ölüm oranı gibi veriler (UNICEF, 2011) eğitimi bir yaşam hakkı olarak da görmeye zorunlu kılmaktadır. Buradan hareketle eğitimin ülke sinırlarının da üzerinde uluslararası bir hak olarak tanımlandığı ve anlaşmalarla güvence altına alındığı söylenebilir. Günümüzde devletlerin eğitimde yapması gereken yükümlülükler; 'İnsan Hakları Evrensel Bildirgesi', 'Ekonomik, Sosyal ve Kültürel Haklar Uluslarası Sözleşmesi', 'Çocuk Hakları Sözleşmesi', 'Kadınlara Karşı Her Türlü Ayrımcılığın Önlenmesi Sözleşmesi', 'Avrupa İnsan Hakları Sözleşmesi' gibi uluslararası sözleşmeler, anayasalar ve yasalar tarafından belirlenmektedir. Yasalarda güvenceye alınmış olmasına rağmen vatandaşların eğitim haklarını kullanabilmeleri, ülkelerin eğitim politikaları ve özellikle de eğitimin finansmanına ilişkin politikalarıyla ilişkilidir (Kayahan Karakul, 2014).

Vatandaşların kaliteli ve kapsayıcı bir eğitim alması için eğitim hizmetlerinin iyi yönetim ve yeterli finansmanla etkili ve adil bir şekilde sağlanması gerekmektedir (ERG, 2019). Eğitimin finansmanı, toplumun eğitim ihtiyacının karşılanabilmesi için gerekli olan mali kaynakların elde edilmesi sürecidir. Bununla birlikte eğitim finansmanı, kaynakların farklı sosyo-ekonomik düzeydeki gruplara ve bireylere, farklı eğitim tür ve kademelere, şehirler ve bölgelere dağılım süreci olarak da tanımlanmaktadır (Altunay, 2017). Dolayısıyla finansmanın nasıl şekillendiği, eğitimin sosyal bir hak olarak adil dağıtımının önemli bir belirleyicisidir.

Türkiye'de eğitim, büyük bir oranda kamu kaynakları ile finanse edilmektedir (OECD, 2020). Kamunun farklı sebeplerle eğitim için beklenen miktarda ödenek ayıramaması veya eğitimin talebindeki artışa paralel yeni kaynak oluşturamaması, eğitimde finansman sorununun ortaya çıkmasına sebep olabilmektedir (Tural, 2002). Bu durumun ana nedeni bahsedildiği üzere eğitimin finansmanında başat unsurun kamusal kaynaklar olmasıdır. Eğitimin finansmanında ek kaynak yaratma sorunsalı; kamusal kaynakların diğer alternatif toplumsal alt kurumlarda da kullanılma ihtiyacı, eğitime ayrılan kaynakların yetersizliği veya aktarılan kaynakların etkin kullanımına yönelik yapılan eleştiriler gibi birçok farklı nedenden ötürü önemli bir problem alanı olarak varlığını hissettirmektedir (Altunay, 2017; Menteşe, Üstün ve Gökdelen, 2012; Özer, Demirtaş ve Ateş, 2015). Nitekim hukuki metinlerde zorunlu ve parasız olduğu belirtilen ilk ve ortaokullarda dahil olmak üzere okulların finansmanının tamamının kamusal kaynaklarla karşılandığını söylemek mümkün değildir. 
İnsan Hakları Evrensel Bildirgesi 26. maddesi 1. bölümünde yer alan "Her şahsın öğrenim hakkı vardır. Öğrenim hiç olmazsa ilk ve temel safhalarında parasızdır. İlköğretim mecburidir. Teknik ve mesleki öğretimden herkes istifade edebilmelidir. Yükseköğretim, liyakatlerine göre herkese tam eşitlikle açı olmalıdır." ifadesi bildirgeye bağlılığını belirten ülkelerin eğitim politikalarını belirleyen önemli etmenlerden biridir. Bildirgenin 1949 yılında Bakanlar Kurulu kararıyla Resmi Gazete'de yayınlanmasıyla Türkiye' de ilköğretimin zorunlu olacağı ve devlet tarafından parasız olarak sunulacağı hukuken güvence altına alınmıştır. Fakat okullar, kendilerinden beklenen eğitim hizmetlerini sunabilmek için gerekli olan finansmanı sağlamada problemler yaşamaya devam etmiştir (Korkmaz, 2005). Kayıkçı ve Akan (2014) okul müdürlerinden okulların finansman problemleri ile ilgili görüş aldıkları çalışmalarında 21 farklı ihtiyaç kalemi belirlemiştir. Yıldız ve Balyer (2019) kamu okullarında giderlerin çok fazla olduğunu, ciddi anlamda mali kaynak sıkıntısı yaşadıklarını ve okulların çeşitli hizmetler sunmada etkisiz kaldığı sonucunu elde etmişlerdir. Hoşgörür ve Aslan (2014) okullardan çağın gereklerine uygun, nitelikli eğitim yapmaları beklendiği halde okulların kaynak oluşturmada güçlükler yaşadığını ve okulların finansmanında kaynakların sınırlı olduğunu belirtmişlerdir.

İlkokul ve ortaokul düzeyinde okullara cari harcamaları için devlet tarafından doğrudan bir nakdi ödenek verilmemektedir. İlkokul ve ortaokullara herhangi bir ödenek verilmemesi, okulların ihtiyaçlarını karşılayabilmesinde sorunlar yaşamasına neden olmaktadır (Karakütük, 2012).

Milli Eğitim Bakanlığının 2020 yılı bütçe sunumunda eğitimin başlıca finansman kaynakları: Merkezi yönetim bütçesinden ayrılan pay, il özel idareleri bütçesinden ayrılan kaynaklar, diş ülke ve kuruluşlardan sağlanan dış kredi, burs ve bağışlar, halk ve kuruluşların eğitime bağışları ile okul-aile birliği gelirlerinden oluşmaktadır (MEB, 2019). Belirtilen finansman kaynaklarının nispeten çeşitliliği teorik olarak okulların mali açıdan belli bir standardın üzerinde olmalarını gerektirmektedir. Ancak okullara doğrudan yansıyan nakdi kaynak, belirtilen gelir kalemleri arasından sadece okul aile birliği gelirleridir. Diğer kaynaklar merkezi olarak kullanılmakta büyük oranda personel giderleri, sosyal güvenlik kurumuna devlet primi ödemeleri ve mal ve hizmet alımlarında kullanılmaktadır (MEB, 2020). Dolayısıyla okullar, öz gelir olarak yarattıkları okul aile birliği gelirleri ile cari harcamalarını karşılamakla baş başa kalmaktadırlar.

Okul gelirlerini artırmak amacıyla içinde bulundukları koşullara göre farklı yollar denemeye (Korkmaz, 2005) başlayan okul yöneticileri, okullara sağlanan kamusal finansmanı ve yaratılan öz gelirleri etkin şekilde kullanma yükümlülüklerinin yanı sıra "girişimcilik", "iletişim" ve "ikna" kabiliyetlerini kullanarak okulun bulunduğu çevrenin finansman desteğini sağlamak durumunda kalmaktadırlar (Erdem, 2019). Okulların öz gelir olarak yarattıkları ve tamamı okul aile birliği gelirine kayıtlı gelirleri farklı kalemlerden oluşabilmektedir.

Türkiye'de okulların finansmanında MEB, yeterli katkı ve desteği sağlayamamaktadır. Bu nedenle okullar, bu konudaki sorunlarını çözebilmek adına öz kaynak yaratma yoluna gitmektedir. Alanyazında okulların öz kaynak yaratma çabalarını kapsayan çok sayıda araştırmaya rastlamak mümkündür. Kavak, Ekinci ve Gökçe (1997) tarafından yapılan, Ankara ili ile sınırlı ancak geniş bir çalışmada, örneklemi kapsayan okulların 27 farklı kaynakla gelir sağladıkları görülmüştür. Bu araştırmada kent ve köy okulları arasında kaynak çeşitliliğinin yanı sıra veli sosyo-ekonomik düzeyinin yansımaları da net olarak görülmüştür. ERG (2014) İlköğretim kurumlarının mali yönetimi başlıklı raporunda, Türkiye'de okulların kendi 
imkanlarıyla 22 ila 60 farklı türde özel gelir kaynağı oluşturduğunu alanyazına dayalı olarak belirtmiştir. Hoşgörür ve Arslan (2014) okul bahçelerini çeşitli etkinlikler için kiralama, kantin geliri, düzenlenen gezi programlarından arta kalan paralar, yıl sonu eğlenceleri, çaylar, kermesler gibi etkinliklerden elde edilen gelirler, çevre şartlarına göre alınan nakdi yardımlar ve gönüllü veli bağışlarını okul aile birliği gelirlerine örnek olarak vermişlerdir. Yamaç (2010) ise farklı olarak okul arması gelirleri, spor kulübü parası, fotoğraf gelirleri, yetiştirme kursu gelirleri, kooperatif gelirleri, deneme sınavi paralarından kalan paylar, merkezi sistem sınavlarına başvuruda alınan paylar, kayıt parası, okul kıyafetleri gelirleri, otopark gelirleri gibi çeşitli kaynakları dile getirmiştir. Sonuç olarak, okul öncesi eğitim kademesinden başlayarak eğitimin bütün kademelerinde, öğrenci velilerinden ya da okul dışındaki kurum, kuruluş ve kişilerden, farklı isimler altında sağlanan ayni veya nakdi yardımlar okulların finansmanı içerisinde önemli bir kalem olarak karşımıza çıkmaktadır (Yıldırım, 2020).

Okulların öz gelir oluşturma ihtiyacının, özellikle yüksek maliyeti olan temizlik ve güvenlik alanlarında ek personel çalıştırma gereksinimine yönelik Türkiye İş Kurumu'nun yürüttüğü Toplum Yararına Çalışma Programı (TYÇP) gibi çözümlerle giderek azaldığı söylenebilir. Ancak yine de okullar halen zorunlu cari harcamalarını karşılamak için gelir yaratma ihtiyacı duymaktadırlar. Okulların gelir kaynakları ve fırsatları ise birbirinden farklılık gösterebilmektedir. Okulların gelir durumunu etkileyen en önemli etken, okulun içinde bulunduğu bölgenin ve dolayısıyla velilerin sosyoekonomik düzeyleridir (Korkmaz, 2005). Okulun bulunduğu bölge ekonomik olarak gelişmiş ise okul yönetiminin mali kaynaklara ulaşması daha kolay olmaktadır. Eğer okulun içinde bulunduğu bölge ekonomik olarak gelişmemiş ise okul yönetiminin bu kaynaklara ulaşması daha da zor hale gelmektedir (Akşahin, 2017). Dolayısıyla bölgelerin, şehirlerin, aynı il içindeki farklı semtlerin bile gelir seviyelerindeki farklılıklar, eğitime destek sağlama konusunda da farklılıklar oluşmasına sebep olmaktadır (Hoşgörür ve Aslan, 2014). Yani okulların yarattı̆̆ı gelirler, okulun içinde bulunduğu çevrenin ve bu çevrede yaşayarak çocuklarını okula gönderen ailelerin gelir seviyeleri arasındaki farklılığa bağlı olarak değişmektedir (Akşahin, 2017; Altunay, 2017; Erdem, 2019; Kavak vd., 1997; Korkmaz, 2005; Kurul, 2012; Önder ve Güçlü, 2014; Özdemir ,2011; Sağ, 2021; Şehitoğlu ve Koçyiğit, 2020; Tezcan, 2017; Yıldız, 2018; Yolcu, 2007)

Okulların mali kaynak noktasında MEB'den gerekli desteği alamaması, buna bağlı olarak öz kaynak yaratmak için çok çeşitli yollara başvurma durumunda kalması ve bu süreçte sorunlarla karşılaşması okulların gelirleri ile ilgili çalışma yapılmasını gerekli kılmaktadır. Okul aile birliği gelirleri, okul çevresinin sosyal ve ekonomik yönden gelişmişlik düzeyi ile doğrudan ilişkili olabilmektedir. Okulların zorunlu çalışma yükümlülüğü kapsamına alınmasında okul çevresinin gelişmişlik düzeyi, (Resmi Gazete, 2015) dikkate alınan değişkenler bakımından önemli bir göstergedir. Bu durum, okulların zorunlu hizmet bölgesinde bulunma durumları, okul aile birliği gelirleri ve okul çevresinin sosyal ve ekonomik yönden gelişmişlik düzeyi arasındaki bağa işaret etmektedir. Bu nedenle, bu araştırmada okul çevresinin sosyal ve ekonomik yönden gelişmişlik düzeyini gösteren zorunlu hizmet bölgesinde olup olmamasının okul aile birliği gelirleri üzerinde belirleyiciliğini araştırmak önemli görülmüştür. 


\section{Araştırmanın Amaç ve Alt Problemleri}

Araştırmanın amacı, okul aile birliği gelirlerinin okulun hizmet alanı sınıflandırmasına göre farklılık gösterip göstermediğinin belirlenmesidir. Bu temel amaç doğrultusunda aşağıdaki sorulara yanıt aranmıştır.

1. İlkokulların okul aile birliği gelirleri hizmet alanına göre anlamlı farklılık göstermekte midir?

2. Ortaokulların okul aile birliği gelirleri hizmet alanına göre anlamlı farklılık göstermekte midir?

3. Liselerin okul aile birliği gelirleri hizmet alanına göre anlamlı farklılık göstermekte midir?

\section{YÖNTEM}

\section{Araştırma Modeli}

Okulların, aile birlikleri aracılığıyla yarattıkları öz gelirlerinin okulun hizmet alanı sınıflamasına göre ne derece farklılaştı̆̆ını incelemeyi amaçlayan çalışma tarama modelinde betimsel olarak tasarlanmıştır. Araştırmanın bağımlı değişkeni eşit oranlı veri olan okul aile birliği gelirleridir. Okul aile birliği gelirleri, okullar arasında karşılaştırma yapabilmek amacıyla öğrenci sayısı ile orantılandırılmıştır. Bağımsız değişken olarak okulların hizmet alanı sınıflandırması alınmıştır. Hizmet alanı sinıflandırması 1. düzeyden 6. düzeye kadar yapılmaktadır. Ancak bu sinıflandırmada 4., 5. ve 6. düzeylerin zorunlu hizmet bölgesi olarak değerlendirilmesi, diğer bölgelerin ise zorunlu hizmet bölgesi olarak değerlendirilmemesi nedeniyle hizmet alanı sınıflandırması zorunlu olan ve olmayan olmak üzere ikili kategorik veriye dönüştürülmüştür. Araştırmanın modeli aşağıda Şekil 1'deki gibi şematize edilebilir:

Şekil 1. Araştırmanın Modeli

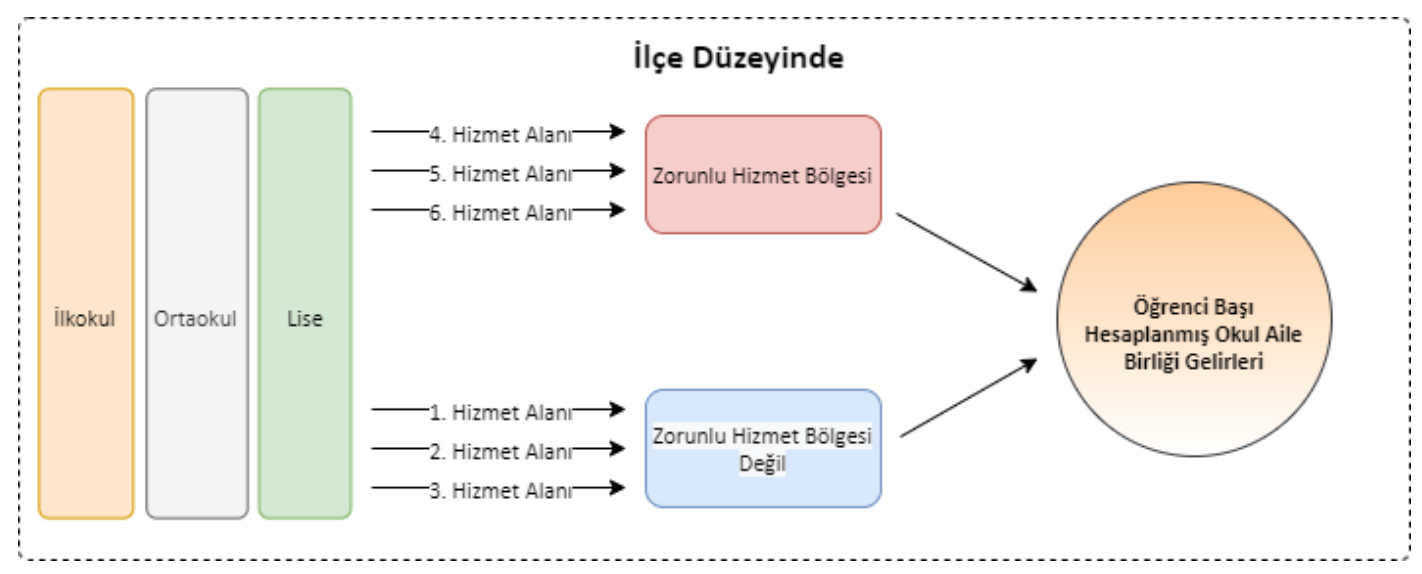

Araştırmada kullanılan veriler, kamuoyuyla ilgili kurumlar tarafında paylaşılıyor olmakla birlikte araştırmacılar tarafından etik kurul izni alınmıştır. Gaziantep Üniversitesi Sosyal ve Beşeri Bilimler Etik Kurulu Komisyonu tarafından çalışmanın amacı, yöntemi, veri kaynakları ve veri toplama araçları değerlendirilmiş, Komisyonun 01.06.2021 tarih ve 08 nolu toplantısında alınan 17 nolu kararıyla etik aykırılık olmadığı bildirilmiştir. 


\section{Evren ve Örneklem}

Araştırmanın çalışma evreni Gaziantep ili merkez ilçeleri resmi ilkokul, ortaokul ve liseleridir. Araştırma kapsamında çalışma evreninin tamamının okul aile birliği gelirleri ile hizmet alanı sınıflamasına ulaşılabildiği için ayrıca bir örnekleme alma yoluna gidilmemiştir. Okullardan bazılarında isim değişikliği, birleşme veya ayrılma gibi durumların tespit edilmesi nedeniyle bu durumdaki okullar örneklemden çıkarılmıştır. Ayrıca okul aile birliği geliri olarak kayıt almaya başlamasına rağmen aktif öğrencisi olmayan veya öğrencisi olmasına rağmen gelir bildirmeyen okullar örnekleme dâhil edilmemiştir.

\section{Verilerin Elde Edilmesi ve Analize Hazırlanması}

Okulların gelir ve öğrenci sayısı bilgileri okulların internet adreslerinden derlenmiştir. Okul aile birliği gelirlerinin pandemi nedeniyle değişkenlik gösterebileceği düşüncesiyle 2019 yılı gelirleri alınmıştır. Okulların hizmet alanı sınıflandırması ise Tebliğler Dergisindeki (Şubat 2021, 2761 no'lu sayısı) alınmıştır. Okul aile birliği gelirlerini gösteren liste ile okulların hizmet alanını gösteren liste Microsoft Office uygulaması olan Excel'de birleştirilmiştir. Liste üzerinde ilçe ve okul düzeyi (ilkokul, ortaokul ve lise) kodları oluşturulduktan sonra veriler SPSS paket programına aktarılmıştır. Bu işlemden sonra veri üzerinde öncelikle uç değer incelemeleri yapılmıştır. Uç değer incelemelerine Mahalanobis uzaklığı hesaplanarak başlanmıştır. Bu aşamada serbestlik derecesine göre Ki-kare değerlerine (3.43) bakılarak örneklemden çıkartılabilecek uç değer gösteren okullar belirlenmiştir. Ancak uç değer incelemesine, çok boyutlu normallik incelemeleri sirasinda Q-Q Plot grafiklerinin incelenmesiyle devam edilmiştir. Silinecek değerlere bu inceleme neticesinde karar verilmiştir. İnceleme sonucunda elde edilen uç değerler ile araştırmaya dahil edilen okul sayıları Tablo 1'de ayrıntılı bir şekilde gösterilmiştir.

Tablo 1. Uç Değer Gösteren Okul Sayıları ile Araştırmaya Dahil Edilen Okul Sayıları

\begin{tabular}{ccccc}
\hline & Gruplar & Toplam Okul Sayısı & Uç Değer & $\begin{array}{c}\text { Araştırmaya Dahil Edilen } \\
\text { Okul Sayıs }\end{array}$ \\
\hline \multirow{2}{*}{ İLKOKUL } & Merkez İlçe 1 & 94 & 6 & 88 \\
\cline { 2 - 5 } & Merkez İlçe 2 & 115 & - & 115 \\
\hline \multirow{2}{*}{ ORTAOKUL } & Merkez İlçe 1 & 78 & 5 & 73 \\
\cline { 2 - 5 } & Merkez İlçe 2 & 79 & 1 & 78 \\
\hline \multirow{2}{*}{ LísE } & Merkez İlçe 1 & 70 & 5 & 50 \\
\cline { 2 - 5 } & Merkez İlçe 2 & 58 & 8 & \\
\hline
\end{tabular}

\section{Verilerin Analizi}

Verilerin analizinde, parametrik testlerin varsayımları karşılandığı durumlarda bağımsız gruplar için t-testi ve tek yönlü varyans analizinden yararlanılmıştır. Bu amaçla öncelikle parametrik testlerin varsayımları sınanmıştır. Verilerin çok boyutlu, normalliği sağlayıp sağlamadığının incelenmesinde çarpıklık- basıklık değerleri (-1 ile +1 aralığı), çarpıklık- basıklık değerlerinin standart hatalarına bölünmesi sonucu elde edilen değerler (-1,96 ile 1,96 aralığı) ve normallik hipotezini test eden Kolmogorov Smirnov'un anlamlılık değerleri birlikte 
incelenmiştir. Verilerin istatistikî anlamlılı̆̆ $\mathrm{p}<0.05$ değeri ile incelenmiştir. Bu değer iki ortalama arasında anlamlı bir farkın olup olmadığını verir ancak bu farkın büyüklüğü hakkında bilgi vermez (Can, 2017). Diğer bir anlatımla istatistikî olarak anlamlı olan verilerin pratik anlamlılığı için etki büyüklüğü hesaplanması gerekmektedir. Bu amaçla ortalamalar arası fark istatistiklerinin etki büyüklügünü belirlemek için sıklıkla kullanılan Cohen's d, Glass' Delta ve Hedges' g değerleri rapor edilmiştir. Cohen (1988) tarafından sırasıyla küçük (0.20), orta (0.50) ve büyük (0.80) etki olarak tanımlanan d değerleri Sawilowsky (2009) tarafından genişletilmiştir. Sawilowsky (2009)'e göre d'nin alabileceği değerler 0.01 ile 2.00 arasındaki değerleri içeren ve çok küçük (0.01), küçük (0.20), orta (0.50), büyük (0.80), çok büyük (1.20) ve oldukça çok büyük (2.00) etki olarak değerlendirilir. Farklı durumlarda farklı etki büyüklükleri öne çıkmaktadır. Örneğin küçük örneklemlerde Hedges'g istatistiği; grupların standart sapma değerleri birbirinden farklı olduğunda ise Glass' Delta daha iyi sonuçlar vermektedir. Dolayısıyla araştırmada üç etki büyüklüğü birlikte rapor edilmiştir.

\section{BULGULAR}

Araştırmanın birinci alt amacı olan merkez ilçelerde yer alan ilkokulların aile birliği gelirlerinin bulundukları hizmet alanı sınıflandırmasına göre farklılık gösterip göstermediğini belirlemeye ilişkin yapılan $\mathrm{t}$ testi sonuçları Tablo 2'de sunulmuştur.

Tablo 2. Ilkokul Aile Birliği Gelirlerinin Hizmet Alanına Göre t-testi Sonuçları.

\begin{tabular}{|c|c|c|c|c|c|c|c|c|c|c|}
\hline & Gruplar & $\mathrm{N}$ & $\bar{X}$ & $S$ & sd & $\mathrm{t}$ & $\mathrm{p}$ & Cohen's d & $\begin{array}{l}\text { Glass' } \\
\text { Delta }\end{array}$ & Hedges' g \\
\hline \multirow{2}{*}{$\begin{array}{c}\text { Merkez } \\
\text { İlçe } 1\end{array}$} & Zorunlu Hizmet Dışı & 19 & 433,93 & 180,18 & \multirow{2}{*}{86} & \multirow{2}{*}{5,25} & \multirow{2}{*}{.00} & \multirow{2}{*}{1,36} & \multirow{2}{*}{2,04} & \multirow{2}{*}{1,74} \\
\hline & Zorunlu Hizmet & 69 & 209,15 & 110,09 & & & & & & \\
\hline \multirow{2}{*}{$\begin{array}{c}\text { Merkez } \\
\text { İlçe } 2\end{array}$} & Zorunlu Hizmet Dişı & 18 & 1072,56 & 443,22 & \multirow{2}{*}{113} & \multirow{2}{*}{16,21} & \multirow{2}{*}{.00} & \multirow{2}{*}{4,16} & \multirow{2}{*}{6,75} & \multirow{2}{*}{4,13} \\
\hline & Zorunlu Hizmet & 97 & 203,02 & 128,92 & & & & & & \\
\hline
\end{tabular}

Tablo 2'de merkez ilçelerde yer alan ilkokulların aile birliği gelirleri hizmet alanı sinıflandırmasına göre anlamlı farklılık göstermektedir $(\mathrm{p}<.01)$. Her iki ilçede de zorunlu hizmet alanı dışında olan okulların aile birliği gelir ortalaması $(\bar{X} 1=433,93 ; \bar{X} 2=1072,56)$ zorunlu hizmet alanı olan ilkokulların aile birliği gelir ortalamasından $(\bar{X} 1=209,15 ; \quad \bar{X} 2=203,02)$ yüksektir. İstatistiksel olarak anlamlı fark bulunan gruplar arasındaki farkın büyüklügüüü belirlemek için hesaplanan etki büyüklüğü (Can, 2018) değerleri incelendiğinde merkez ilçe 1 için elde edilen 1.36 Cohen's d değerinin çok büyük; merkez ilçe 2 için elde edilen değerin ise oldukça çok büyük olduğu (Sawilowsky, 2009) söylenebilir.

Araştırmanın ikinci alt amacı olan merkez ilçelerde yer alan ortaokulların aile birliği gelirleri bulundukları hizmet alanı sınıflandırmasına göre farklılık gösterip göstermediğini belirlemeye ilişkin yapılan $\mathrm{t}$ testi sonuçları Tablo 3'te verilmiştir. 
Tablo 3. Ortaokul Aile Birliği Gelirlerinin Hizmet Alanına Göre t-testi Sonuçları.

\begin{tabular}{|c|c|c|c|c|c|c|c|c|c|c|}
\hline & Gruplar & $\mathrm{N}$ & $\bar{X}$ & $S$ & $\mathrm{sd}$ & $\mathrm{t}$ & $\mathrm{p}$ & Cohen's d & $\begin{array}{l}\text { Glass' } \\
\text { Delta }\end{array}$ & Hedges' g \\
\hline \multirow{2}{*}{$\begin{array}{c}\text { Merkez } \\
\text { İlçe } 1\end{array}$} & Zorunlu Hizmet Dışı & 18 & 312,76 & 144,63 & \multirow{2}{*}{71} & \multirow{2}{*}{6,89} & \multirow{2}{*}{.00} & \multirow{2}{*}{1,87} & \multirow{2}{*}{2,4} & \multirow{2}{*}{1,85} \\
\hline & Zorunlu Hizmet & 55 & 132,09 & 75,32 & & & & & & \\
\hline \multirow{2}{*}{$\begin{array}{c}\text { Merkez } \\
\text { İlçe } 2\end{array}$} & Zorunlu Hizmet Diş1 & 20 & 510,87 & 247,37 & \multirow{2}{*}{76} & \multirow{2}{*}{11,37} & \multirow{2}{*}{.00} & \multirow{2}{*}{2,95} & \multirow{2}{*}{6,35} & \multirow{2}{*}{2,92} \\
\hline & Zorunlu Hizmet & 58 & 112,38 & 62,8 & & & & & & \\
\hline
\end{tabular}

Tablo 3'te merkez ilçelerde yer alan ortaokulların aile birliği gelirleri hizmet alanı sinıflandırmasına göre anlamlı farklılık göstermektedir ( $\mathrm{p}<.01)$. Her iki ilçede de zorunlu hizmet alanı dışında olan okulların aile birliği gelir ortalaması $(\bar{X} 1=312,76 ; \bar{X} 2=510,87)$ zorunlu hizmet alanı olan ilkokulların aile birliği gelir ortalamasından $(\bar{X} 1=132,09 ; \bar{X} 2=112,38)$ yüksektir. Elde edilen ortalamalar arasındaki farkın büyüklügüne ilişkin hesaplanan etki büyülükleri çok büyük etki olarak yorumlanabilir.

Araştırmanın üçüncü alt amacı olan merkez ilçelerde yer alan liselerin aile birliği gelirleri bulundukları hizmet alanı sınıflandırmasına göre farklılık gösterip göstermediğini belirlemeye ilişkin yapılan $\mathrm{t}$ testi sonuçları Tablo 4 'te yer almaktadır.

Tablo 4. Lise Aile Birliği Gelirlerinin Hizmet Alanına Göre t-testi Sonuçları.

\begin{tabular}{|c|c|c|c|c|c|c|c|c|c|c|}
\hline & Gruplar & $\mathrm{N}$ & $\bar{X}$ & $S$ & $\mathrm{sd}$ & $\mathrm{t}$ & $\mathrm{p}$ & Cohen's d & $\begin{array}{l}\text { Glass' } \\
\text { Delta }\end{array}$ & Hedges' g \\
\hline \multirow{2}{*}{$\begin{array}{c}\text { Merkez } \\
\text { İlçe } 1\end{array}$} & Zorunlu Hizmet Dışı & 25 & 438,9 & 231,05 & \multirow{2}{*}{63} & \multirow{2}{*}{1,87} & \multirow{2}{*}{0.07} & \multirow{2}{*}{-} & \multirow{2}{*}{-} & \multirow{2}{*}{-} \\
\hline & Zorunlu Hizmet & 40 & 310,89 & 288,99 & & & & & & \\
\hline \multirow{2}{*}{$\begin{array}{c}\text { Merkez } \\
\text { İlçe } 2\end{array}$} & Zorunlu Hizmet Dışı & 20 & 587,45 & 270,34 & \multirow{2}{*}{48} & \multirow{2}{*}{4,83} & \multirow{2}{*}{.00} & \multirow{2}{*}{1,39} & \multirow{2}{*}{1,71} & \multirow{2}{*}{1,37} \\
\hline & Zorunlu Hizmet & 30 & 280,32 & 180,17 & & & & & & \\
\hline
\end{tabular}

Tablo 4'te merkez ilçe 1'de yer alan lise okul aile birliği gelirleri hizmet alanı sınıflandırmasına göre anlamlı farklılık göstermemektedir ( $\mathrm{p}>.05)$ Merkez ilçe 2' de yer alan liselerde ise hizmet alanı sınıflandırmasına göre anlamlı farklılık görülmüştür $(\mathrm{p}<.01)$. Merkez ilçe $2^{\prime}$ de yer alan liselerden zorunlu hizmet alanı dışında olan okulların aile birliği gelir ortalaması $(\bar{X} 2=270,34)$ zorunlu hizmet alanı olan ilkokulların aile birliği gelir ortalamasından $(\bar{X} 2=180,17)$ yüksektir. Cohen's d istatistiği elde edilen manidar farkın etki değerinin $(1,36)$ büyük olduğuna işaret etmektedir. Diğer bir anlatımla, istatistikî olarak anlamlı olan bu fark gerçek anlamda da yararlı olduğunu büyük bir etkiye karşılık geldiğini göstermektedir.

\section{TARTIŞMA VE SONUÇ}

$\mathrm{Bu}$ araştırmada ilkokul, ortaokul ve lise düzeylerinde okul aile birliği gelirlerinin okulların hizmet alanı sınıflandırmasına göre farklılık gösterip göstermediğinin belirlenmesi amaçlanmıştır. Araştırmada elde edilen bulgular, literatürde yapılmış çalışmaları desteklemektedir. 
Araştırmadan elde edilen bulgular, her iki merkez ilçedeki zorunlu hizmet alanı dışındaki ilkokulların okul aile birliği gelirlerinin, zorunlu hizmet alanı olan ilkokulların okul aile birliği gelirlerinden daha yüksek olduğunu; her iki merkez ilçedeki zorunlu hizmet alanı dışındaki ortaokulların okul aile birliği gelirlerinin, zorunlu hizmet alanı olan ortaokulların okul aile birliği gelirlerinden daha yüksek olduğunu ve lise düzeyinde ise her iki merkez ilçedeki zorunlu hizmet alanı dışındaki liselerin okul aile birliği gelirlerinin, zorunlu hizmet alanı olan ortaokulların okul aile birliği gelirlerinden daha yüksek olduğunu ortaya koymaktadır. Ayrıca, okulun zorunlu hizmet alanı olması ile okul aile birliğinin yükselmesi arasında pozitif yönde doğrusal bir ilişki gözlenmiştir. Bu bulgular, sosyo-ekonomik düzeyi yüksek bölgelerde bulunan okulların, sosyo-ekonomik düzeyi düşük bölgelerde yer alan okullara göre daha fazla öz kaynak oluşturduklarını göstermektedir. Özdemir (2011) yapmış olduğu çalışmaya göre, okulların içinde bulunduğu çevrenin sosyo-ekonomik düzeyi arttıkça okul aile birliklerinden elde ettikleri gelirlerde de artış olduğunu tespit etmiştir. Bu anlamda araştırmamızdan elde ettiğimiz bulguların bu araştırmayla benzerlik gösterdiği söylenebilir. Kurul'a (2012, s. 314) göre öz kaynak oluşturma noktasında okulların içinde bulunduğu bölgelerin sosyo-ekonomik düzeyindeki farklılıkların, okullar arasında önemli düzeyde fırsat ve imkân eşitsizliklerine yol açtığ1 gözlenmiştir. Yolcu (2007), Ankara' da yapmış olduğu çalışmada, sosyo-ekonomik düzeyi yüksek bölgelerde bulunan okulların, orta ve alt sosyo-ekonomik düzey bölgelerde bulunan okullara göre daha fazla gelir kaynakları elde ettiğini ifade etmiştir. Araştırmadan elde ettiğimiz bulgular Akşahin (2017), Altunay (2017), Yıldız (2018) ve Sağ (2021) tarafından yapılan çalışmalardan elde edilen bulguları da desteklemektedir. Ayrıca uluslararası alanyazında doğrudan okul aile birliği gelirleri ile okul bölgesi arasındaki ilişkiyi araştıran çalışmalar olmasa $\mathrm{da}$, aile sosyo ekonomik düzey veya statüsüyle başarı arasındaki ilişkiyi araştıran çalışmalar benzer konuya ilgiyi göstermektedir. Bu açıdan yaklaşıldığında ailenin sosyo-ekonomik düzeyinin dolayısıyla okul bölgesinin öğrenci başarısı üzerinde etkisi olduğuna yönelik çalışmalar bulunmaktadır (Benito, Alegre ve González-Balletbó, 2014; Caldas ve Bankston, 1997; Guthrie, Kleindorfer, Levin ve Stout, 1971; Owens, 2018). Caldas ve Bankston (1997) öğrencilerin tek tek sosyo-ekonomik düzeyinden daha çok okul nüfusunun diğer bir anlatımla öğrencinin akranlarının genel sosyo ekonomik düzeyine odaklanarak çevrenin başarı üzerine etkisini göstermiştir. Dixson, Keltner, Worrell ve Mello (2018) yapmış oldukları çalışmada farklı bir yaklaşımda sosyo-ekonomik düzey ile akademik başarı arasındaki ilişkide umudun aracılığına odaklanarak, aslında yüksek sosyo ekonomik düzey algısının daha yüksek umuda sahip olunmasına kaynaklık ettiğini bunun da başarı üzerindeki olumlu etkilerini göstermişlerdir. Mancebón-Torrubia ve Ximénez-de-Embún (2014) İspanya'da ortaokul son sınıf öğrencilerinin okul tercihleri üzerine odaklandıkları çalışmalarında, sosyo-ekonomik düzeyin belirleyiciliğine işaret etmektedirler. Guthrie (1971) yoksul mahallelerin yoksul okulları olduğunu ve Amerika'da iyi eğitimin orta ve üst sınıfların ayrıcalığı olduğunu belirtmektedir. Owens (2018) yapmış olduğu araştırmada, yüksek gelire sahip öğrencilerin daha avantajlı bölgelerdeki okullara, düşük gelire sahip öğrencilerin ise daha dezavantajlı bölgelerdeki okullara gittiğini tespit etmiştir. Böylece okulların okul finansmanı gibi hususlarda birbirlerinden ayrışmalarına sebep olduğunu belirtmektedir. Bu bulguların araştırmadan elde ettiğimiz bulguları desteklediği söylenebilir.

MEB Okul Aile Birliği Yönetmeliğinin 18. maddesinde, birlik gelirlerinin okulun bütçe disiplini çerçevesinde eğitim-öğretim giderleri ile maddi imkânlardan yoksun öğrencilerin ihtiyaçlarının 
giderilmesi amacıyla harcanmasının esas olduğu belirtilmiştir. Araştırmanın bulgularından elde edilen sonuçlara göre, okul aile birliklerinin gelirleri arasındaki mevcut farklılaşma sebebiyle eğitim-öğretim giderlerinin dezavantajlı okullarca karşılanabilmesinin mümkün olmadığı anlaşılmaktadır. Mezkûr maddede belirtilen, maddi imkânlardan yoksun öğrencilerin ihtiyaçlarının birlik gelirlerinden karşılanma gerekliliğinin de, bu koşullarda sağlanmasının zor olduğu söylenebilir. Çünkü henüz okulun günlük ihtiyaçlarını dahi karşılamakta zorluk yaşayan bir bütçeden sosyal yardım sağlamasını beklemek zordur. Aynı zamanda okul aile birliği gelirlerinin velilerce yapılan bağışlardan da oluşması, bağış yapan velilerin okul içinde ayrıcalıklı olmak istemelerine de sebep olabilir. Araştırmanın sonuçlarına göre, okul aile birliği gelirleri, okulun içinde bulunduğu bölgenin sosyo-ekonomik düzeylerinden etkilenmektedir. Şehitoğlu ve Koçyiğit (2020) de İsviçre ve Türkiye'nin okul aile birliği sistemlerini karşılaştırdıkları çalışmada, okulda yapılan etkinliklerin okul aile birliği aracılığıyla velilerden alınan bağış ve yardımlara dayandığını dolayısıyla sosyo-ekonomik koşulların okul aile birliğinin uygulamalarını şekillendirdiğini belirlemişlerdir. Hatta aynı çalışmada katılımcı olarak görüş beyan eden bir okul müdürü, güçlü velinin güçlü okul demek olduğunu ifade ederek bu durumu açıklamıştır. Ayrıca aynı çalışmada İsviçre'de okulların kendilerine ait bütçeleri olması ve okul aile birliklerince öğrenciler arasında eşitliği sağlamak ve bireylerin ayrıcalık istemelerine engel olmak için gönüllülerden bağış alınmamasının da çalışmamızın bulgularını desteklediği söylenebilir. Bu açıdan konuya yaklaşıldığında, birlik gelirlerinin yüksek olduğu okullarda ihtiyaç sahibi öğrencilerin az olması; birlik gelirlerinin düşük olduğu okullarda ise ihtiyaç sahibi öğrencilerin çok olması beklenir. Bu durumda ihtiyaç sahibi öğrenci başına düşen yardım miktarı da önemli oranda farklılaşacaktır. Bu sonucun, fırsat ve imkân eşitliği çerçevesinde değerlendirildiğinde sosyal adalet ilkesinin zedelenmesine yol açacağ söylenebilir. Aslanargun, Bozkurt ve Sarıŏlu (2016) çalışmalarında velilerin gelir düzeyinin öğrencilerin başarısı üzerinde etkili olduğu sonucuna ulaşmışlardır. Buna göre gelir düzeyi yüksek velilerin çocukları eğitimlerinde daha başarılı olabilmektedir. Öğrenciler arasında eşitsizliğe neden olan bu sonucun çalışmamızın bulgularıyla örtüştüğü söylenebilir. Okulun, öğrencilerin okul dışından getirdiği fırsat eşitsizliklerini azaltması beklenirken bu sonuçların mevcut farklılıkları daha da derinleştireceği ifade edilebilir. Bu olumsuz tablo, 21. yüzyıl Türkiye' sinin eğitim sisteminin çözmesi gereken bir problem alanı olarak politika belirleyicilerin önem vermesi gereken bir konu olarak değerlendirilmelidir.

Okul aile birliği gelirlerinin zorunlu hizmet alanı dışındaki okullar lehine farklılaşması, zorunlu hizmet alanı olan okulların öz kaynak oluşturma konusunda dezavantajlı konumda olduklarını göstermektedir. Okul aile birlikleri gelirlerinin bağışlar ve kantin gelirleri başta olmak üzere okul çevresinden sağlandığı düşünüldüğünde zorunlu hizmet alanındaki okulların sosyoekonomik koşullar açısından, zorunlu hizmet alanı dışındaki okullara göre daha yoksul toplum kesimlerini barındırdığ 1 ve bunun da okul aile birliği gelirlerine doğrudan yansıdığ söylenebilir. Buradan hareketle bu okulların öz kaynak oluşturmada yetersiz kaldıkları ve mali desteğe ihtiyaç duydukları söylenebilir. Önder ve Güçlü (2014) tarafından eğitim alanında faaliyet gösteren dernek, sendika ve vakıflardan oluşan örneklem grupla yapılan çalışmada, kamudan ayrılan kaynakların her okula eşit bir şekilde dağıtılmasının yerine, kaynak dağılımında okulların sahip olduğu koşullar baz alınarak pozitif ayrımcılık yapılması gerektiği vurgulanmiştır. 
$\mathrm{Bu}$ çalışma sonuçları, okullar arasındaki finansman eşitsizliğini göstermesi bakımından önem taşımaktadır. Okul finansmanındaki bu eşitsizliğin okullarda eğitimin tüm boyutlarını olumsuz etkileyeceği söylenebilir, bu nedenle okullar arasında çeşitli alanda farklılıklar oluşabilir veya mevcut farklılıklar derinleşebilir. Oysa MEB 2023 Vizyon Belgesinde hem temel eğitim hem de ortaöğretim ile ilgili 3. hedefin okullar arası başarı farkını azaltmak olduğu görülmektedir. Altunay (2017)'a göre ülkemizde okulların finans kaynakları noktasında, okullar ve bölgeler arasında var olan sosyo-ekonomik düzey farklılığı nedeniyle öğrencilerin öğrenme olanakları olumsuz etkilenmektedir. Zira Yolcu'nun (2007) yapmış olduğu araştırmaya göre yüksek sosyoekonomik düzeydeki okullar, diğer düzeylerdeki okullardan farklı bir şekilde gelirlerini eğitimin kalitesini artırmak için kullanmaktadır. Orta ve alt düzeydeki okullar ise gelirlerini zorunlu giderlere ayırmak durumunda kalmaktadır. Özdemir (2011), okulların sosyo-ekonomik düzeyi ile öğrencilerin Matematik, Fen ve Teknoloji ve Türkçe testlerinden elde ettikleri sonuçlar arasında pozitif yönde doğrusal bir ilişki tespit etmiştir. Yıldırım (2020)'a göre gelir düzeyi düşük okulların müdürleri velinin gözünde itibar kaybı yaşarken bu müdürler, eğitim-öğretim faaliyetlerinden daha çok okula finansman sağlamakla uğraşmaktadırlar.

$\mathrm{Bu}$ araştırmanın bir başka sonucu da okulların hizmet alanlarının sınıflandırılması ile birlik gelirlerinin tutarlılık göstermesi olarak değerlendirilebilir. MEB Öğretmen Atama ve Yer Değiştirme Yönetmeliği 39. maddesinde okulun bulunduğu yerin sosyo-ekonomik gelişmişlik düzeyinin okulların zorunlu çalışma yükümlülüğü kapsamına alınmasında dikkat edilen ölçütler arasında olduğu ifade edilmektedir. Zorunlu hizmet alanındaki okulların aile birliği gelirlerinin anlamlı farklılık göstermesi okulların Tebliğler Dergisindeki (Şubat 2021, 2761 no'lu sayısı) hizmet alanı sınıflandırmasına uygun olarak ayrıştı̆̆ını göstermesi açısından önem arz etmektedir.

Her iki merkez ilçede ilkokulların aile birliği gelirlerinin ortalamalarının zorunlu hizmet alanı dışındaki ilkokullar arasında da farkın çok yüksek olduğunu göstermektedir. Bunun merkez ilçelerin de gelişmiş yerleşim yerlerinin birbirinden farklı koşullara sahip olduğu anlamına geldiği söylenebilir. Her iki merkez ilçenin okul türüne göre okulların aile birliği gelirlerinin ortalaması sıralandığında ortaokulların aile birliği geliri açısından en sonda yer aldığı görülmektedir. Bu durum, ortaokulların sosyo-ekonomik koşullardan en olumsuz etkilenen eğitim kademesi olduğunu göstermektedir. Alanyazında bu bulgumuzu destekleyen araştırmalar bulunmaktadır. Altunay (2017) yapmış olduğu araştırmada, okul kademeleri arasında okul finansman açısından en dezavantajlı okulların ortaokullar olduğunu tespit etmiştir. Tezcan (2017), okul yöneticilerinin görüşlerinden yapmış olduğu çalışmada, ortaokulların finansmanı noktasında en önemli ve temel sorunun okulun bulunduğu çevredeki sosyo-ekonomik farklılıklar olduğu sonucunu elde etmiştir. Erdem (2019) ise yapmış olduğu araştırmada, ortaokul yöneticilerinin öz kaynak oluşturmada ailelerden yeterli desteği alamadığını vurgulamıştır. Bu sonuçlar, araştırma bulgumuzla benzerlik göstermektedir.

\section{ÖNERILER}

Okul kantinlerinin okul aile birliklerinin önemli bir gelir kalemini oluşturduğu bilinmektedir. Dezavantajlı yerlerdeki okulların öğrenci sayıları yüksek olsa bile kantin geliri daha düşük olabilmektedir. Mevzuat gereği (Okul Aile Birliği Yönetmeliği Madde 17) büyükşehir statüsünde olan illerde kantin gelirlerinin yüzde 3'ü hazineye kalanının yüzde 10'u il milli eğitim müdürlüğü yüzde 10’u da ilçe milli eğitim müdürlüğüne ödenmektedir. Bu durumda bir 
okulun kantin gelirinden yüzde 22.4 oranında bir kesinti daha ilk başta yapılmaktadır. Araştırmanın sonuçlarına göre okul aile birliği geliri düşük olan zorunlu hizmet alanındaki okular il ve ilçe milli eğitim müdürlüklerine ödenen paydan muaf tutulabilir.

Okul finansmanı bağlamında ele alındığında araştırmamızda elde edilen sonuçların eğitim açısından iç acı olmadığı söylenebilir. Mevcut durum, okulların adeta kendi yağlarında kavrulduklarını göstermektedir. Bu sonuçlarla okul hedeflerinin gerçekleşmesi mümkün görünmemektedir. MEB yetkilileri okulların sesini duymalı, düzenli bir şekilde okulların finansmanını sağlamalı, sosyal ve ekonomik çevrenin belirleyici olduğu bir eğitimin niteliğini tartışmalıdır. MEB 2023 Vizyon Belgesinde okul finansmanı başlığı altında belirtildiği üzere;

- Her okula, oluşturulacak çeşitli ölçütlere ve Okul Gelişim Planı'na dayalı okul gelişim bütçesi verilmesi,

- Şartları elverişsiz okullara pozitif ayrımcılık yapılması,

- Okul aile birliği gelirlerinin yeni bir yapıya kavuşması

olarak sıralanan hedeflerin hayata geçirilmesi için geç kalınmamalı, okulların kendi şartlarına göre kendilerini geliştirebilecekleri yapı ve modeller hayata geçirilmelidir. Çevresel şartların olumsuz, hatta yıkıcı mali etkilerinden okullar korunmalıdır.

Araştırmanın sonucuna göre ortaokulların birlik geliri ortalamalarının en düşük olan eğitim kademesi olduğu görülmektedir. Ortaokulların bu durumu gözetilerek yapılacak desteklerde bu eğitim kademesine öncelik verilebilir.

Eğitimin önemli bir sacayağı olan okul finansmanı ihmal edildiğinde devletin eğitim için ayırdığı devasa bütçenin de aslında beklenen sonuçları vermeyebileceği hesaba katılmalıdır.

Okulların mali durumlarının doğuracağı eşitsizlikler dikkate alınmalı, okullar arasında oluşacak her türden imkan farklılıklarının doğrudan bireyler arasında eşitsizliklere neden olacağı unutulmamalı. Sosyal adalet anlayışına politikalarda öncelik verilmelidir.

Velilerin okullara bağışlar yapmaları, okulun gelirlerini artıracak etkinliklerde yer almaları önemli görülebilir ancak okula parasal anlamda katkıda bulunan velilerin okul işlerinde yöneticileri ve öğretmenleri zor durumda bırakacak talepleri veya ayrıcalık beklentilerinin de ortaya çıkabileceği unutulmamalıdır. Bu sorunların baş göstermemesi adına velilerin etkisini minimize edecek şekilde okulların finansman problemleri ele alınmalıdır.

\section{ÖTE ARAŞTIRMA}

Okulların aile birliği geliri açısından farklılaşması sadece finansman için önemli bir sorun olarak görülmemeli aynı zamanda bu sorunun okul içinde farklı alanlarda da etkisini hissettirebileceği bilinmelidir. Bundan dolayı bu araştırmanın sonuçlarına göre bu okullarda verilen eğitimin niteliği, okul müdürleri ve öğretmenlerin bu sonuçlar hakkındaki görüşlerini paylaşan nitel veya karma desenli çalışmalar yapılabilir.

$\mathrm{Bu}$ çalışmada okul aile birliklerinin gelirleri incelenmiştir. Yeni araştırmacılar okul aile birlikleri gelirlerinin kalemlerinin neler olduğunu ve bu gelirlerin nasıl harcandığını ortaya çıkaracak çalışmalar yaparak okul finansmanı probleminin daha iyi anlaşılabilmesine katkı sağlayabilir. 
Birlik gelirlerinden maddi imkândan yoksun öğrencilerin yararlandırılmaları ilgili mevzuatta değinilen bir konudur. Yapılacak bir çalışmada okul aile birliği gelirlerinden bu öğrencilere ne kadar destek sağlandığı sosyal adalet ilkesi çerçevesinde incelenebilir.

\section{KAYNAKÇA}

Akşahin, H. (2017). İlkokulların finansal kaynak sorunları ve bu sorunların aşılması için yapılan stratejilerin değerlendirilmesi. Yüksek lisans projesi, Yakındoğu Üniversitesi, Lefkoşa.

Altunay, E. (2017). Okul yöneticilerinin görüşleri doğrultusunda eğitim finansmanı politikaları: Sorunlar, nedenler ve çözümler. Bartın Üniversitesi Eğitim Fakültesi Dergisi, 6(2), 689-784. https://doi.org/10.14686/buefad.304498

Aslanargun, E., Bozkurt, S. \& Sarığlu, S. (2016). Sosyo ekonomik değişkenlerin öğrencilerin akademik başarısı üzerine etkileri. Uşak Üniversitesi Sosyal Bilimler Dergisi, 9(3), 216-234. https://dergipark.org.tr/tr/pub/usaksosbil/issue/24734/261548

Benito, R., Alegre, M. Á., \& González-Balletbó, I. (2014). School segregation and its effects on educational equality and efficiency in 16 OECD comprehensive school systems. Comparative Education Review, 58(1), 104-134. https://doi.org/10.1086/672011

Caldas, S. J., \& Bankston, C. (1997). Effect of school population socioeconomic status on individual academic achievement. The Journal of Educational Research,90(5), 269-277. https://doi.org/10.1080/00220671.1997.10544583

Can, A. (2017). SPSS ile bilimsel araştırma sürecinde nicel veri analizi. Pegem Akademi.

Cohen, J.(1988). Statistical power analysis for the behavioral sciences. Routledge.

Dixson, D. D., Keltner, D., Worrell, F. C. \& Mello, Z. (2018). The magic of hope: Hope mediates the relationship between socioeconomic status and academic achievement. The Journal of Educational Research, 111(4), 507-515. https://doi.org/10.1080/00220671.2017.1302915

Erdem, A. R. (2019). Milli Eğitim Bakanlığı'na bağlı okulların finansmanı. V. INES Human and Civilization Congress From Past To Future, Full Text Book, 798-805.

ERG (2014). İlköğretim kurumlarının mali yönetimi. Eğitim Reformu Girişimi. http://www.egitimreformugirisimi.org/wpcontent/uploads/2017/03/ERG MaliYonetimArastirmaRaporu.pdf

ERG (2019). Eğitimin yönetişimi ve finansmanı. Eğitim Reformu Girişimi. https://www.egitimreformugirisimi.org/wpcontent/uploads/2017/03/EIR YonetisimVeFinansman.16.05.19.rev1 .pdf

Guthrie, J. W., Kleindorfer, G. B., Levin, H. M. \& Stout, R. T. (1971). Schools and inequality. Mass The MIT Press.

Hoşgörür, V. \& Arslan, İ. (2014). Okul örgütünün finansal kaynaklarının yönetimi sorunu (Yatağan ilçesi örneği). Trakya Üniversitesi Eğitim Fakültesi Dergisi, 4(1), 911022. https://dergipark.org.tr/tr/pub/trkefd/issue/21473/230155 
Kavak, Y., Ekinci, E. \& Gökçe, F. (1997). İlköğretimde kaynak arayışları. Kuram ve Uygulamada Ĕ̆itim Yönetimi Dergisi, 3(3), 309-320. https://dergipark.org.tr/tr/pub/kuey/issue/10384/127055

Kayahan Karakul, A. (2014). İran ve Türkiye'de eğitim finansmanının karşılaştırılması. Mehmet Akif Ersoy Üniversitesi Eğitim Fakültesi Dergisi, 31, 67-87. https://dergipark.org.tr/tr/pub/maeuefd/issue/19404/206222

Kayıkçı, G. \& Akan, D. (2014). İlköğretim kurumlarının mali kaynak sorunları ve okul müdürlerinin çözüm uygulamaları. Akademik Sosyal Araştırmalar Dergisi, 2(1), 237-255.

Korkmaz, İ. (2005). İlköğretim okullarının karşılaştıkları finansman sorunları. Selçuk Üniversitesi Eğitim Fakültesi Dergisi, 14 429-434. https://dergipark.org.tr/tr/pub/susbed/issue/61791/924088

Kurul, N. (2012). Eğitim finansmanı. Siyasal Kitabevi.

Mancebón-Torrubia, M. J., \& Ximénez-de-Embún, D. P. (2014). Equality of school choice: a study applied to the Spanish region of Aragón. Education Economics, 22(1), 90-111. https://doi.org/10.1080/09645292.2010.545197

MEB (2019). MEB 2020 yılı bütçe sunuşu. Milli Eğitim Bakanlığı. https://sgb.meb.gov.tr/meb iys dosyalar/2019 12/18094404 2020 BUTCE SUNUYU 1 7.12.2019.pdf

MEB (2020). 2019-2020 Milli eğitim istatistikleri örgün eğitim. Milli Eğitim Bakanlığ1. http://sgb.meb.gov.tr/meb iys dosyalar/2020 09/04144812 meb istatistikleri orgun e gitim 2019 2020.pdf

Menteşe, S. Üstün, A. \& Gökdelen, A. (2012). İlköğretim okulu yöneticilerinin okulun parasal kaynaklarını yönetme yeterlikleri (Ordu il örneği). Hitit Üniversitesi Sosyal Bilimler Enstitüsü Dergisi, 5(2), 41-65. https://dergipark.org.tr/tr/pub/hititsosbil/issue/7713/101002

OECD (2020). Education at a glance 2020: OECD indicators. OECD Publishing. https://doi.org/10.1787/19991487

Owens, A. (2018). Income segregation between school districts and inequality in students' achievement. Sociology of Education, 91(1), 1-27. https://doi.org/10.1177/0038040717741180

Önder, E. \& Güçlü, N. (2014). İlköğretimde okullar arası başarı farklılıklarını azaltmaya yönelik çözüm önerileri. Eğitim Bilimleri Dergisi, 40(40), 109-132. https://dergipark.org.tr/tr/pub/maruaebd/issue/389/2708

Özdemir, N. (2011). İlköğretimin finansmanında bir araç: Okul-aile birliği bütçe analizi (Ankara ili örneği). Yüksek lisans tezi, Hacettepe Üniversitesi, Ankara.

Özer, N. Demirtaş, H. \& Ateş, Ö. F. (2015). Okulların mali durumlarına ve bütçe yönetiminde yaşanan sorunlara ilişkin müdür görüşleri. e-Uluslararası Eğitim Araştırmaları Dergisi, 6(1), 17-39. https://doi.org/10.19160/e-ijer.17651

Psacharopoulos, G. \& Woodhall, M. (1993). Education for development. Oxford University Press. 
Sağ, K., Ş. (2021). Kamu okullarının finansman sorunları ve eğitim öğretime yansımaları. Yüksek lisans tezi, Marmara Üniversitesi, İstanbul.

Sawilowsky, S. (2009). New effect size rules of thumb. Journal of Modern Applied Statistical Methods. 8(2), 467-474. https://doi.org/10.22237/jmasm/1257035100

Schultz, T. P. (2002). Why governments should invest more to educate girls. World development, 30(2), 207-225. https://doi.org/10.1016/S0305-750X(01)00107-3

Şehitoğlu, M. \& Koçyiğit, M. (2020). Türkiye ve İsviçre'de okul aile birliği: Bir karşılaştırma çalışması. Uluslararası Yönetim Akademisi Dergisi, 3(3), 632-653. https://doi.org/10.33712/mana.825942

Tezcan, Ö. E. (2017). Ortaokullarda finansman ve finansman yönetiminin incelenmesi (Gaziantep ili örneği). Yüksek lisans tezi, Gaziantep Üniversitesi, Gaziantep.

Tural, N. (2002). Eğitim finansmanı. Anı Yayıncılık.

UNICEF. (2011). Türkiye'de çocukların durumu raporu. Milli Eğitim Bakanlığı Avrupa Birliği ve Dış İlişkiler Genel Müdürlügü. https://abdigm.meb.gov.tr/projeler/ois/egitim/032.pdf

Yamaç, U. (2010). Illköğretim okullarının finans kaynakları. Yüksek lisans tezi, Pamukkale Üniversitesi, Denizli.

Yıldırım, R. (2020). Okullara yapılan bağış̧lar. Tezsiz yüksek lisans projesi, Pamukkale Üniversitesi, Denizli.

Yıldız, S. (2018). Neoliberal ekonomi uygulamalarıyla eŏitim finansmanı ve okul paydaşlar ilişkisinin değişimi. Yüksek lisans tezi, Yildız Teknik Üniversitesi, İstanbul.

Yıldız, S. \& Balyer, A. (2019) Okul paydaşları bağlamında kamu okullarındaki parasal sorunlar: Fenomenolojik bir araştırma. Pamukkale Üniversitesi Ĕ̆itim Fakültesi Dergisi, 46(46), 349364. https://doi.org/10.9779/pauefd.463715

Yolcu, H. (2007). Türkiye'de ilköğretim finansmanının değerlendirilmesi. Doktora tezi, Ankara Üniversitesi, Ankara. 